\title{
Construction and Application of Engineered Bacteria for Bioaugmentation Decolorization of Dyeing Wastewater: A Review
}

\author{
X. H. Xie*, N. Liu, H. Jiang, L. Y. Zhu \\ College of Environmental Science and Engineering, Donghua University, Shanghai, China \\ Email: xiexuehui@dhu.edu.cn, liujianshe@dhu.edu.cn
}

Received January 2014

\begin{abstract}
With the development of dyeing wastewater treatment biotechnology, the advantages of bioaugmentation bacteria gradually catch people's eyes. Therefore, its construction and application research has also attracted the attention of the majority of scholars. This article summaries the construction and application of bioaugmentation engineered bacteria used to treat dyeing wastewater in recent years, including the screening, domestication and application of single and mixed flora bacteria. In addition, the impact of the strengthening effect of all genes is also described in this paper. Finally, the optimization and promoted use of bioaugmentation bacteria are out looked.
\end{abstract}

\section{Keywords}

Bioaugmentation; Engineered Bacteria; Decolorization; Dyeing Wastewater

\section{Introduction}

With the rapid development of the economy, the displacement of the printing and dyeing industry has increased significantly. According to the incomplete statistics, annual emissions of printing and dyeing wastewater are about 20 million tons, generally accounted for from $60 \%$ to $80 \%$ of the integrated discharge, which ranks fifth in the country's industrial wastewater emissions (Wang et al., 2012). Therefore, the treatments of industrial wastewater are becoming more and more difficult. Dye used in printing and dyeing industry is mostly synthetic dye. And the join of some new additives, PVA size etc makes printing and dyeing wastewater has the features of large chromaticity, great ranges of COD changes, high alkalinity, poor biodegradability, big fluctuation of water temperature and quantity.

In recent years, the application of biological strengthening technology in dying wastewater treatment attracts the eyes of many scholars, which refers to adding microbes with specific functions into the original biological

*Corresponding author.

How to cite this paper: Xie, X. H. et al. (2014). Construction and Application of Engineered Bacteria for Bioaugmentation Decolorization of Dyeing Wastewater: A Review. Journal of Geoscience and Environment Protection, 2, 84-88. 
treatment system in order to improve its treatment effect (Han, 1999). The use of strengthening bacteria in dealing with other wastewater such as the wastewater containing pyridine and petrifaction also confirmed its powerful processing capability (Qiao et al., 2012; Ma et al., 2008), and the bacteria used in treating azo dye have got some achievements, and its biological decolorizing research also had certain progress (Saratale et al., 2011; Manjinder et al., 2005; Anjali et al., 2007; Song et al., 2003). The bioaugmentation engineered bacteria used in the decolorization of printing and dyeing wastewater are more and more widely. Dosing microorganisms with special degradation to the printing and dyeing wastewater treatment system can greatly increase the decolorization effect of wastewater.

\section{Engineered Bacteria and Its Construction for Bioaugmentation}

Engineered bacteria can be divided into special engineered bacteria and generalized engineered bacteria. Special engineered bacteria refer to separating certain target genes with various degrading properties, and then obtain various degradative effects within it through gene operations that can degrade a variety of new types of organics. However, generalized engineered bacteria is a mixed flora reasonably combined by the high efficiency degradation bacteria which were separated, screened and identified from natural environment, polluted environment and treatment systems, and it can degrade various organics efficiently (Ma et al., 2008), which leads to its widely application.

\subsection{Genetic Engineered Bacteria}

Constructing genetic engineered bacteria to deal with environmental issues is the front topics in environmental biotechnology, which combined modern biotechnology with environmental problems. Genetic engineered bacteria can be directed effectively to use contaminant-degrading gene in microbial cells to perform the function of purifying pollutants.

Jin et al. (2005) firstly constructed genetic engineered bacteria pGEX-AZR/E. coli JM-109 possessing the ability of degradation of azo dyes, the results indicated that genetic engineered bacteria possess high efficiency in various azo dyes treatments, especially the small molecular one. Through constructing metagenomic library with large insert fragments, Gou et al. (2012) proved that the activated sludge Fosmid library can be used to actively screening functional genes, and it also has the potential to develop new genes, and lay the foundation for building the genetic engineered bacteria.

Due to the low success rate, high cost, and long adaption time of genetic engineered bacteria expression, and certain problems of hereditary, purification function and biosafety, its applications are not widely. Besides, there are some difficulties in the promotion.

\subsection{Generalized Engineered Bacteria}

Generalized engineered bacteria for bioaugmetation refer to the high effect bacteria strains separated and domesticated from activated sludge that treating printing and dyeing wastewater, and they have special degradation function of printing and dyeing wastewater pollutants.

The bioaugmetation engineered bacteria reported so far are mostly separated from sludge and polluted environment and then domesticated into apply (Chen et al., 2003; Yue et al., 2003; Zou et al., 2012; Wang et al., 2009; Li et al., 2011). One mixed bacterial consortia SKB-II was isolated from a textile wastewater treatment plant by Bella et al. (2009). This consortium has good effect for decolorizing individual as well as mixture dyes. At $1.0 \mathrm{~g} / \mathrm{L}$ starch supplementation, the decolorization rate reached 80-96\% of a single dye (Congo red, Bordeaux red, etc.), and for mixture dyes the decolorization rate also reached 50-60\% when present as a mixture at 10 $\mathrm{mg} / \mathrm{L}$. In order to adapt to the reactors, the researchers generally fixed constructed engineered bacteria on suspended solids or fixed carrier by immobilization technology. After isolating high efficient bacteria consortia from wastewater activated sludge, Ma et al. (2008) put them into the reactor. After treating, the effluent water quality is better than the first standard of Table 2 in Integrated Wastewater Discharge Standard (GB8978-1996).

\section{Application of Bioaugmentation Engineered Bacteria}

\subsection{Application of Individual Bacteria Strain}

In recent years, the application of bioaugmetation engineered bacteria dealing with wastewater became more and 
more widely. There are more and more scholars constructed them to treat printing and dyeing wastewater, and also obtained some achievements.

A processing metal composite azo dyes Shiva's strain J18 143 was screened by Tie et al. (2010). The concentration of wastewater after treating could reach $0.12 \mathrm{~g} / \mathrm{L}$. Other scholars also isolated high efficient decolorization activity bacteria (Zhang et al., 2010). Although single bacteria possess good decolorization capacity, its applications in treating real wastewater are hard to be achieved. On one hand, the enzyme production and color removal of single bacteria can hardly adapt to the complex components of wastewater, on the other hand, the problems of the contamination of other bacteria cannot be solved (Yang et al., 2007; Brown et al., 1993). In order to overcome the limitations of single bacteria, the majority of scholars began to focus on the application of mixed consortium.

\subsection{Application of Mixed Bacteria Consortium}

Mixed bacteria consortium refer to a micro-ecological system in which two or more microorganisms reach the advantage of its largest group of the combined effects through common culture, interaction and mutual influence. The organic matter in dyeing wastewater may be degradated more thoroughly and completely due to the co-metabolism between a variety of bacteria. So the decoloration rate and the degradation effects of mixed bacteria consortium are all better than single bacteria. There have been many scholars engaging in screening and domesticating mixed bacteria consortium so far (Safia et al., 2007; Saratale et al., 2009). Taruna et al. (2008) screened a bacteria consortium TJ-1 which possesses the degradation capacity of acid orange 7 and a lot of azo dyes wastewater. The decolorization rate of TJ-1 is higher than single bacteria which prove that there are interactions among the bacteria. After treating AO7 solution $16 \mathrm{~h}$ at the concentration of $200 \mathrm{mg} / \mathrm{L}$, the decolorization rate had reached $90 \%$ which showed perfect effects.

In addition to bacteria, many fungi also possess the capacity of treating dyeing wastewater, and many scholars also combined them together to explore the treatment effect (Kurade et al., 2012; Lade et al., 2012). Many scholars not only limited to do the laboratory research of mixed bacteria consortium, but also combined it with the reactor in order to achieve the application and promotion of mixed bacteria consortium in engineering.

\subsection{Applications of Engineered Bacteria Combined Reactor}

In recent years many bacteria consortia screened are applied to the reactor, and handled a large number of the dyeing wastewater combined with the role of the reactor resulted in achieving a good effect (Xu et al., 2010; Xu et al., 2010). Imen et al. (2012) used a sequencing batch reactor (SBR) inoculated with an acclimated novel microbial consortia 'Bx' to enhance a reactive dye Blue Bezaktiv S-GLD 150 dye. The experiment results indicated that under aerobic conditions the decolorization rate and removal rate of COD arrived 88-97\% and 95-97\% respectively at volumetric dye loading rates under $15 \mathrm{~g}$ dye/m3.d.

Bioengineering bacteria greatly enhanced the effect of wastewater treatment, as well as a successful biotechnology case applied in wastewater. After understanding the processing capacity of bio-engineered bacteria, how to optimize its performance is also one of the issues explored by the researchers.

\subsection{Bioaugmetation Effects of the Xenobiotics}

The bioaugmetation effects of the engineered bacteria have been tested by many experiments. On the base of screening and domesticating engineered bacteria, through optimizing the nutrient supply of the existing treatment system and adding the matrix (substrate) analogs, many scholars improved the vitality of the engineered bacteria or stimulate microbial growth, which lead to further strengthening treatment of the dyeing wastewater.

The group of Zhou jiti researched the role of anthraquinone intermediates on the decolorization strengthening of the dyeing wastewater (Jiao et al., 2009; Su et al., 2008; Wang et al., 2011; Guo et al., 2006; Fang et al., 2007). They examined the catalytic strengthening effects of quinone reduction bacteria in decolorizing azo dyes by six anthraquinone dye intermediates, and proved the augmentation effect of xenobiotics on engineered bacteria, and confirmed that the addition of the engineered bacteria did not damage the structure and characteristics of the original system. As a result, they optimized the engineering bacteria to improve its handling capacity (Guo et al., 2006; Xing et al., 2007). 


\section{Prospects}

Bioaugmentation engineered bacteria occupies an irreplaceable position in the printing and dyeing wastewater treatment because of its various advantages, including powerful treatment capability, good decolorization effect, and little impact on the community structure of the original processing system and so on. Addition be added directly to the processing system, bio-engineered bacteria can also firstly be combined together when construction, and then put into use. Through the interaction between the bacteria consortium, the decolorization effect and degradation rate of the system are improved.

Adding biological engineered bacteria to reactors achieved the binding of engineered bacteria and treatment process, and optimized the treatment process. Traditional treatment technology itself has a processing capacity and load carrying ability, and screened engineered bacteria possessing good decolorizing ability significantly enhanced the processing capacity of the entire system. At the same time, the practical application of engineered bacteria has been extended, and the study of all aspects of its performances owned more practical significance. During the treatment process of bioaugmentation engineered bacteria, the addition of some xenobiotics optimized the performances of engineered bacteria, as well as improved its dyeing wastewater treatment ability and decolorization effects.

The decolorization of bioaugmentation engineered bacteria has been studied, and many efficient bacteria consortia have been screened and domesticated so far. But Further strengthening the engineered bacteria, further putting engineered bacteria into large-scale use, achieving its value are the direction we should strive as well as the goal of our struggle.

\section{Acknowledgements}

This work was supported by the Ph.D. Programs Foundation of Ministry of Education of China Young Scholars (No. 20120075120014), the Shanghai Natural Science Foundation of Youth Project (No. 12ZR1440400), the Shanghai Leading Academic Discipline Project (B604), the State Environmental Protection Engineering Center for Pollution Treatment and Control in Textile Industry.

\section{References}

Anjali, P., Poonam, S., \& Leela, I. (2007). Bacterial Decolorization and Degradation of Azo Dyes. International Biodeterioration \& Biodegradation, 59, 73-84.

Bella, D. T., Dinesh, G., \& Sunil, K. (2009). Decolorization of Textile Azo Dyes by Aerobic Bacterial Consortium. International Biodeterioration \& Biodegradation, 63, 462-469.

Brown, M. A., \& de Vito, S. C. (1993). Predicting Azo Dye Toxicity. Critical Reviews in Environmental Sciences and Technology, 23, 249-324. http://dx.doi.org/10.1080/10643389309388453

Chen, K. C., Wu, J. Y., Liou, D. J., \& Hwang, S. J. (2003). Decolorization of the Textile Dyes by Newly Isolated Bacterial Strains. Journal of Biotechnology, 101, 57-68. http://dx.doi.org/10.1016/S0168-1656(02)00303-6

Fang, L. F., Wang, J., Zhou, J. T., Li, L. H., \& Lv, H. (2007). Biological Decolourzation Quinone Compound Enhancing Azo Dyes. China Environmental Science, 27, 174-178.

Gou, M., Qu, Y. Y., Zhou, J. T., Xu, B. W., \& Cao, X. Y. (2012). Construction of Metagenomic Fosmid Library from Activated Sludge. Journal of South China University of Technology (Natural Science Edition), 40, 120-123.

Guo, J. B., Zhou, J. T., Wang, D., Tian, C. P., Wang, P., Wang, J., Salah, U., \& Li, L. H. (2006). Accelerating Effects of Immobilized Anthanquinone on the Anaerobic Biodegradation. Environmental Science, 27, 2071-2075.

Han, L. P. (1999). Bioaugmentation for Removal of Recalcitrant Organics. Environmental Science, 20, 100-102.

Imen, K., Beno, M., \& Raja, B. A. (2012). Treatment of Reconstituted Textile Wastewater Containing a Reactive Dye in an Aerobic Sequencing Batch Reactor Using a Novel Bacterial Consortium. Separation and Purification Technology, 87, 110-119.

Jiao, L., Lv, H., Zhou, J. T., Cui, D. T., \& Wang, J. (2009). Isolation, Identification and Characteristics of Quinone Compounds Enhancing Dye-Decolorizing Bacterium. China Environmental Science, 29, 191-195.

Jin, Y. J., Jin, R. F., Wang, J., \& Zhou, J. T. (2005). Researches on the Fermentation of Genetic Engineering Microorganism and the Decolorization of Azo Dyes. Industrial Safety and Environmental Protection, 31, 10-12.

Kurade, M. B., Waghmode, T. R., Kagalkar, A. N., \& Govindwar, S. P. (2012). Decolorization of Textile Industry Effluent Containing Disperse Dye Scarlet RR by a Newly Developed Bacterial-Yeast Consortium BL-GG. Chemical Engineering 
Journal, 184, 33-41. http://dx.doi.org/10.1016/j.cej.2011.12.058

Lade, S. H., Waghmode, T. R., Kadam, A. A., \& Govindwar, S. P. (2012). Enhanced Biodegradation and Detoxification of Disperse Azo Dye Rubine GFL and Textile Industry Effluent by Defined Fungal-Bacterial Consortium. International Biodeterioration \& Biodegradation, 72, 94-107. http://dx.doi.org/10.1016/j.ibiod.2012.06.001

Li, H., Qu, Y. Y., Shi, S. N., \& Zhou, J. T. (2011). Isolation and Characterization of a Dye-Colorizig Bacterial Strain. Microbiology China, 38, 523-530.

Ma, F., Guo, J. B., Zhao, L. J., \& Shan, D. (2008). The Construction and Application of Engineering Bacteria for Bioaugmented Treatment of Petrochem Icalwastewater. Acta Scientiae Circumstantiae, 28, 885-891.

Manjinder, S. K., Harvinder, S. S., Deepak, K. S., Bhupinder, S. C., \& Swapandeep, S. C. (2005). Decolorization of Various Azo Dyes by Bacterial Consortium. Dyes and Pigments, 67, 55-61.

Qiao, L., Zhao, H., \& Wang, J. L. (2012). Bioaugmented Removal of Pyridine and the Microbial Community Dynamic Analysis. Environmental Science, 33, 2052-2060.

Safia, M., Xama, K., \& Datta, M. (2007). Isolation, Characterization and Decolorization of Textile Dyes by a Mixed Bacterial Consortium JW-2. Dyes and Pigments, 74, 723-729.

Saratale, R. G., Saratale, G. D., Chang, J. S., \& Govindwar, S. P. (2011). Bacterial Decolorization and Degradation of Azo Dyes: A Review. Journal of the Taiwan Institute of Chemical Engineers, 42, 138-157.

Saratale, R. G., Saratale, G. D., Kalyani, D. C., Chang, J. S., \& Govindwar, S. P. (2009). Enhanced Decolorization and Biodegradation of Textile Azo Dye Scarlet R by Using Developed Microbial Consortium-GR. Bioresource Technology, 100, 2493-2500. http://dx.doi.org/10.1016/j.biortech.2008.12.013

Song, Z. Y., Zhou, J. T., Wang, J., Yan, B., \& Du, C. H. (2003). Progress on Bio-Decolorization of Azo-Dye Wastewater. Environmental Science and Technology, Supplement 26, 78-80.

Su, Y. Y., Wang, J., Zhou, J. T., Lv, H., \& Li, L. H. (2008). Enhanced Biodecolourization of Azo Dyes by the Catalysis of Anthraquinone Dyes Intermediators. Environmental Science, 29, 1986-1991.

Taruna, J., Leela, I., Karunakar, S., \& Sanjeev, G. (2008). Isolation, Identification and Application of Novel Bacterial consor-tiumtj-1 for the Decolourization of Structurally Different Azo Dyes. Dyes and Pigments. Bioresource Technology, 99, 7115-7121.

Tie, L., \& James, T. G. (2010). Colour Removal from Aqueous Solutions of Metal-Complex Azo Dyesusing Bacterial Cells of Shewanella Strain J18 143. Bioresource Technology, 101, 4291-4295.

Wang, H., Zheng, X. W., Su, J. Q., Tian, Y., Xiong, X. J., \& Zheng, T. L. (2009). Biological Decolorization of the Reactive Dyes Reactive Black 5 by a Novel Isolated Bacterial Strain Enterobacter sp. EC3. Journal of Hazardous Materials, 171, 654-659. http://dx.doi.org/10.1016/j.jhazmat.2009.06.050

Wang, J. F., Zhao, Y. W., \& Mao, Y. F. (2012). Research Progress of Printing and Dyeing Wastewater Treatment. China's Environmental Protection Industry, 4, 30-33.

Wang, J., Su, Y. Y., Li, L. H., Lv, H., Jin, R. F., \& Zhou, J. T. (2011). Enhanced Biodecolorization of Azo Dyes by Co-Immobilization of Quinone-Reducing Consortium and Anthraquinone. Journal of Dalian University of Technology, 51, 174-179.

Xing, L. L., Wang, J., Qu, Y. Y., Zhou, J. T., Lv, H., \& Guo, J. B. (2007). Microbial Characteristics and Community Analysis of Bioaugmented MBR System. Chinese Journal of Environmental Engineering, 1, 70-73.

Xu, H. L., Bai, J. Y., Zhang, Y. D., \& Wang, H. R. (2010). Pilot Study on Treatment of Printing and Dyeing Wastewater by Bioaugmentation Technology. China Water \& Wastewater, 26, 91-93.

Xu, Q. K., \& Wang, X. J. (2010). Application of Biological Aerated Filter Process to Treatment of Dyeing and Printing Wastewater. Environmental Science \& Technology, 33, 177-180.

Yang, Q. X., Jia, Z. J., Li, H. J., Chen, J. J., \& Zhang, H. (2007). Decolorization, Enzyme Production and Community Analysis of High Efficiency Decolorization Microbe Consortium. China Environmental Science, 27, 763-767.

Yue, Y. Q., Zhu, H. G., \& Wang, S. F. (2003). Isolation and Identification on a Strain of High-Efficient Dye Decolorizing Bacteria and Their Characteristics of Decolorization. Shanghai Environmental Sciences, 22, 556-558.

Zhang, S. Q., Chen, Bi. Q., Yang, G., Li, C., \& Cao, Z. A. (2010). Screening and Characteristics of Azo Dye Decoloring Alkali Resistant Bacteria. China Biotechnology, 30, 76-80.

Zou, X. Z., \& Li, M. Z. (2012). A Study on Cultivation and Decolorization Performances of a Degradation Strain for Reactive Blue FNR. Dyestuffs and Coloration, 49, 56-58. 